\title{
Transformation towards sustainability: public space in the city centres of Varaždin and Ivanić-grad
}

\begin{abstract}
The aim of the present article is to show how spatial, morphological, and functional transformation of public space contributes to aspects of sustainability. Research methodology encompasses two levels of urban structure consideration. The first level refers to the area of the city centre, and the second level refers to selected public area in the city centre. Criteria and indicators for the evaluation of planned interventions in public spaces were set and divided into topics of traffic, landscape, facilities, and urban equipment. The relationship between the research project results and the principles of sustainability stated in the Basque Declaration was analysed in order to confirm the hypothesis and possible impact of interventions in the context of achieving sustainability and sustainable development on the local level. It can be concluded that planned activities of transformation and contemporary design of public spaces on the local level have multiple positive effects and add to well-being in the wider spatial context of the city, thus also contributing to the global issue of sustainability.
\end{abstract}

Key words: spatial activation, hybrid features, public space system, sustainable development

\section{Introduction}

The topic of sustainability and sustainable development has been relevant in scientific and professional domain for more than three decades and still represents the basis of numerous spatial planning documents at all levels. By establishing relation between visions and actions, and their contribution to sustainability, we want to emphasize the importance of the local level in the planning of cities and towns, relying on the adopted documents. The European Conferences on Sustainable Cities and Places have produced three documents highlighting the main guidelines and activities that European cities and towns should follow and implement on their path to sustainability: Aalborg Charter (1994), Aalborg Commitments (2004), and Basque Declaration: New pathways for European cities and towns (2016). Based on the Aalborg Charter as a basic document explaining why local authorities should pursue sustainable development, the Aalborg Commitments were adopted, with their ten topics explaining what needs to be done to achieve sustainable development on the local level. The Basque Declaration clarifies how these transformations can be implemented with the aim of achieving productive, sustainable, and resilient cities for a liveable and inclusive Europe. The document is set to support and accelerate socio-cultural, socio-economic, and technological transformations to ensure decent quality of life while respecting the constraints of local and global ecosystems and available natural resources. The declaration acknowledges the need for transformation to decarbonize energy systems, create sustainable urban mobility patterns, protect and enhance biodiversity and ecosystem services, reduce the use of greenfield land and natural space, protect water resources and air quality, adapt to climate change, improve public space, provide adequate housing, guarantee social inclusion, and strengthen local economies. The topic of public spaces of the city centre opens numerous different themes and problems that we need to 
refer to in this research when considering public space in the context of the social, economic, and environmental aspects of sustainability.

The city centre has always been of great importance to the city. Despite efforts to stimulate diffuse polynuclear development of the city, Maretić (1996) points out that the main city centre remains a superior focus, the bearer of tradition, representation, and prestige. In the sociological, psychological, and functional sense, it is a place where man as a social being confirms himself, realizing numerous activities and making numerous social contacts. The city centre enables the dynamics of various activities due to numerous facilities and public spaces that represent the connective tissue of the centre, places of socialization, and integration of residents and visitors, thus achieving social dynamics. Therefore, these spaces represent great potential for the city, and carefully designed interventions can often encourage their liveability and transformation of the surrounding space (Petrović Krajnik et al., 2013). Apart from a special role for the wider city area, urban centres also possess a symbolic meaning with emphasized historical significance. Approaches to planning in protected areas such as city centres are particularly sensitive and require subtle sensibility of architects and urban planners, while community engagement must be an integral part of planning and urban design as Polat and Tümer Yildiz (2019) point out.

One of the significant problems in the city centre, and thus in its public spaces, is traffic. Increasing use of private motorized transport has led to congestion in the city centre and numerous negative impacts on the quality of urban life. In order to meet urban sustainability standards, many European cities are conceiving and developing strategies to reduce or eliminate private motorized transport in the centre. New urban mobility plans in cities are focused on improving public transport, encouraging non-motorized modes, creating pedestrian zones, limiting the use of private cars, and otherwise trying to undo the transformation of cities caused by automobile dominance (European Commission, 2004; Pojani \& Stead, 2015).

The public spaces of the centre can be viewed multidimensionally, dealing with different aspects that overlap on different scales. They can be viewed as a specific area, i.e. a location in the city, or as a system of public spaces that connect the urban fabric of the centre. Each part of the system has its own specifics, significance and function, and the system must be considered in a broader spatial context. As Farr (2008) points out, one of the most promising signs for the practice of sustainable urbanism is the diversity of project scales. During the $20^{\text {th }}$ century, public spaces, especially streets, were designed on the principle of car domination, whereas nowadays they have acquired a completely different character, becoming places of multiple modes of transport. In the very centre they become exclusively pedestrian zones, conceived on the idea of liveability in order to contribute to the overall quality of life in the city (Miller et al., 2013; Pojani \& Stead, 2015). Aman et al. (2019) point out that to introduce the concept of living streets in a city is to make the city lively and accessible for its inhabitants, thus encouraging transformation of public spaces. This concept also enables the promotion of healthy communities, better quality of life, improvement of neighbourhood conditions, and the encouragement to use public space (Carmona, 2010; Gehl, 2011; Gehl, 2013). Architects and urban planners strive to design public spaces in a pedestrian attractive way. Here, setting up urban equipment that is not merely attractive but also enables and encourages urban dynamics can play an important role. In addition to equipment, urban landscape is also significant for the compound well-being of citizens and the overall quality of life in the centre. In this research we especially want to point out the importance of public spaces in cities and towns as the optimal elements of urban structure on which the contribution and the suitability of interventions affecting aspects of sustainability can be studied and evaluated. It is hypothesized that the 
transformation of the public space of the city centre can contribute to sustainability and sustainable development. The aim of the present article is to show how spatial, morphological, and functional transformation of public space contributes to the aspects of sustainability.

\section{Research methodology}

As a basis for evaluation of planned public space transformation in the context of sustainability, a review of analysis of selected case studies with general data and historical features of cities, spatial planning documentation of city centres, problems of public spaces, and proposals for their transformation and activation is given. In order to connect scientific research and teaching for the purpose of this research, the city of Varaždin and the town of Ivanić-Grad were selected. Each of the two urban centres was the subject of a master's thesis (on urban planning and architectural proposal for public spaces in Varaždin city centre and on urban planning and architectural proposal for public spaces in the centre of Ivanić-Grad). For the purpose of the present article, research methodology encompassing two levels of consideration of urban structure has been set up. The first level refers to the area of the city centre, and the second level refers to a selected public area in the city centre. By considering the importance of public spaces of the city centre in the context of sustainability and by dividing their physical appearance into formative elements, criteria and indicators for the evaluation of planned interventions in public spaces for each consideration level were set, divided into topics of traffic, landscape, facilities, and urban equipment. The set of criteria and indicators is considered in the period before and after the proposed spatial interventions. For research purposes, quantitative and qualitative methods are used to evaluate proposed interventions and place them in the context of sustainability.

Since the research analyses the physical structure of public spaces, quantitative evaluation methods of planned interventions and their contribution to sustainability aspects are primarily used. Quantitative indicator features are indirectly manifested qualitatively through comparison of existing situations and planned interventions in observed areas. Since these are projects that have not been implemented, contribution to social aspects of sustainability has been considered consequently through the contribution of the physical structure to social aspects of sustainability. For the purpose of the comparison given in the discussion, the results of the evaluation analysis of intervention proposals in two reference periods are presented graphically and with tables. In conclusion, the relationship between the research project results (on different topics of the two considered levels) and the principles of sustainability stated in the Basque Declaration was analysed to confirm the hypothesis and possible impact of interventions in the context of achieving sustainability and sustainable development on the local level (Table 6).

\section{Case Studies - Varaždin and Ivanić-Grad}

This chapter is a review of the analysis of selected case studies with general data and historical features of cities, spatial planning documentation of city centres, problems of public spaces, and proposals for their transformation and activation. The analysed data represents the basis for evaluation of planned interventions in the context of sustainability in two time periods at two considered levels in two selected examples of cities. The results are presented in Chapter 4. 
Table 1: Comparative presentation of general indicators of the considered case studies.

\begin{tabular}{lrr}
\hline & VARAŽDIN & IVANIĆ-GRAD \\
\hline City area (ha) & 5,945 & 17,357 \\
Area of urban settlement (ha) & 2,772 & 2,320 \\
$\begin{array}{l}\text { Population of the city (inhab.) } \\
\text { Number of inhabitants of the }\end{array}$ & 46,946 & 14,548 \\
urban settlement (inhab.) & 39,839 & 9,379 \\
\hline Area of city centre (ha) - first & 38 & 12 \\
level of consideration & & 1.2 \\
$\begin{array}{l}\text { Area of analysed public space (ha) } \\
- \text { second level of consideration }\end{array}$ & 1.4 & \\
\hline Source: Prostorni plan uređenja grada Varaždina (2005); Prostorni plan uređenja grada Ivanić-Grada (2017).
\end{tabular}

\subsection{Varaždin}

The city of Varaždin is located in the northwestern part of continental Croatia. The total area of the city is 5,945 ha and consists of 10 settlements with a total population of 46,946. The central settlement of Varaždin with 39,839 inhabitants is a significant political, cultural, and economic centre of northwestern Croatia. The city centre covers an area of 38 ha (Table 1).

\subsubsection{Historical features}

The area of formerly fortified town, the present urban centre, has a particular importance in the urban structure of the city. During the $12^{\text {th }}$ and $13^{\text {th }}$ centuries, a civic settlement developed as a suburb south of the aristocratic town, which received its first fortifications in the middle of the $15^{\text {th }}$ century. The transformation of Varaždin's medieval fortifications according to Italian Renaissance fortification style began in the middle of the $16^{\text {th }}$ century due to its newly significant strategic role. The subsequent modernization of Varaždin's fortifications was the first example of the emergence of a bastion-type fortification in Croatia. The modernized fort retained its shape and size until its demolition after 1807. Dismantling Varaždin's fortifications at the beginning of the $19^{\text {th }}$ century enabled the creation of public urban spaces and construction of predominantly public buildings on the site of former fortifications, similar to numerous examples of urban transformation in European cities (Žmegač, 2000; Krajnik, 2007; Krajnik \& Śćitaroci, 2007). Transformation of fortifications opened the possibility of design and arrangement of new public spaces. These newly designed places were located on the site of former bastion fortifications, and have a representative character and special significance in the urban fabric (Figure 1a). 

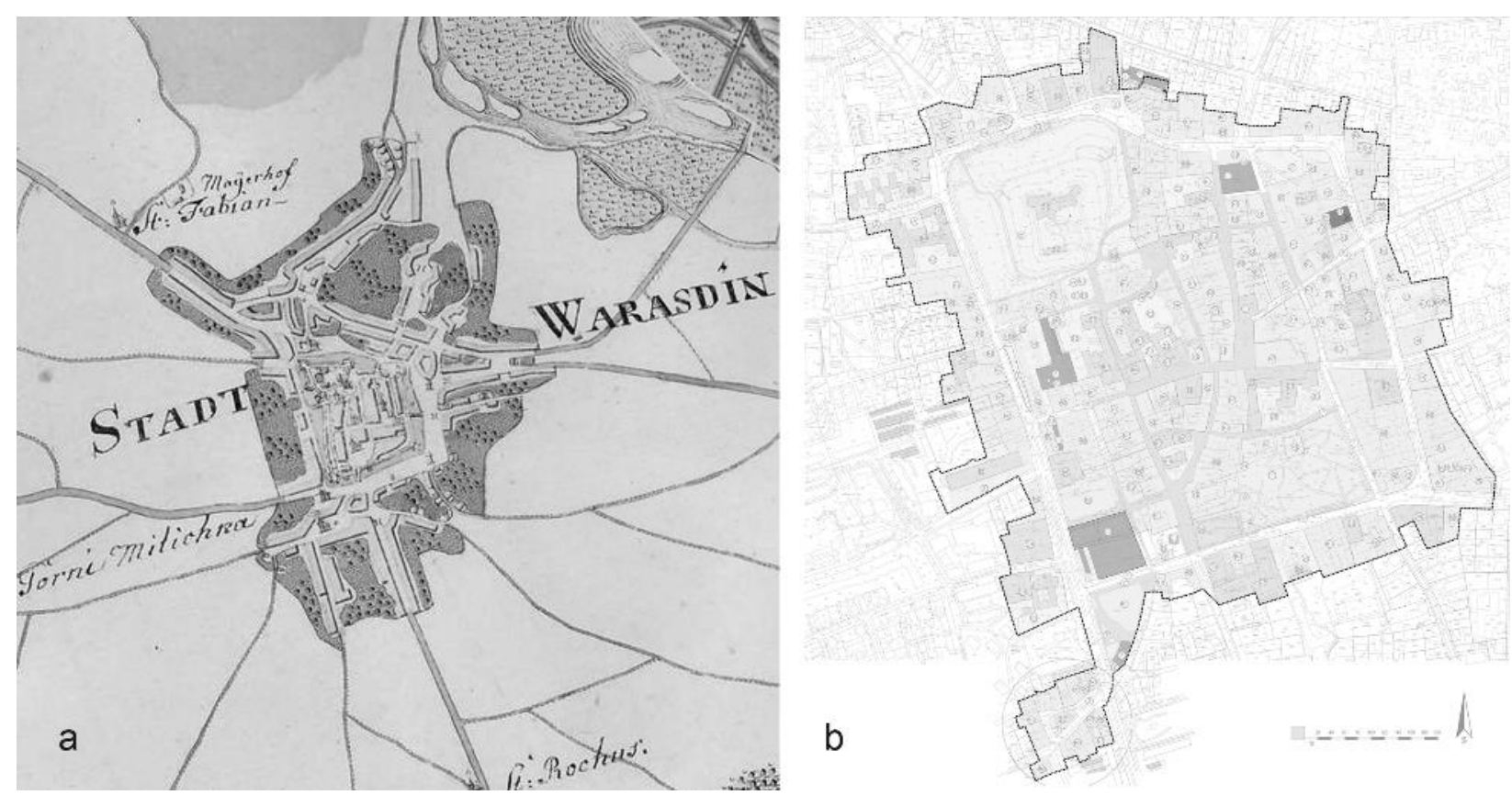

Figure 1: a) Varaždin on first military survey of the Habsburg Monarchy (1764-1784) (source: https://mapire.eu/en/); b) Urban Development Plan of the historic core of the city of Varaždin (2006) (source: Urbanistički plan uređenja povijesne jezgre grada Varaždina, 2019).

\subsubsection{Spatial planning documentation}

The Urban Development Plan of the historic core of the city of Varaždin (2006) and its amendments (2013 and 2019) show that the analysed area is mainly planned for public and social use, with mixed use being predominantly devoted to economic/business purposes, while a significant part of the area is intended for public parks. Courtyards next to public buildings are planned as public green areas, enabling the addition of the existing system of landscaped areas of the city centre. Two underground garages are planned in the centre area, one in the north and the other one in the southwest along the ring road. Additionally, there would be a parking lot for residents of the urban insula in the eastern part of the centre. Parking lots are also provided in the profile of the perimeter roads. Through construction of the already mentioned underground garages, the plan envisages the expansion of the existing pedestrian zone and the abolition of parking lots (Figure 1b). The city centre of Varaždin is one of the most important Baroque-Rococo-Classicist historical architectural and urban sites in Croatia, with preserved architectural heritage that has been enlisted in the Register of Immovable Cultural Monuments of Republic of Croatia.

\subsubsection{Problems of public space in the city centre}

The analysis of the current traffic infrastructure indicates that the city centre is overloaded with cars, especially during peak hours. The existing parking spaces in the profile of the centre's roads, the public parking lot in the northwestern part of the centre, and the newly built public garage in the southeastern part of the centre do not have the capacity to meet the needs for parking space of residents and visitors. The analysis of public spaces in the centre indicates that the city has a clearly defined pedestrian zone, with the possibility of expansion to the contact area. Perimeter squares (Ban Josip Jelačić Square and the Freedom Square) represent a potential for integration into the pedestrian zone which would significantly reduce the carload on the centre and enable more space for pedestrian use. Some of the streets that are an integral part of the pedestrian zone are without urban equipment and have a transit function only. Courtyards next to public buildings that are currently neglected and not in use also represent the potential to become new public spaces. The analysis shows that apart from the landscaped areas of the 
northern and southern part of the centre, which are the result of the transformation of bastion fortification system, the centre itself does not have areas with high vegetation, except for the Freedom Square, Gaj Street, Paulines Street, and Franciscan Square. The city centre is active throughout the year with different occasions depending on public areas, while emphasized social activity is noticed during various public events periodically taking place in the city. The analysis of present situation of the centre of Varaždin pointed out the need for redefinition of public spaces and interventions aiming to create a better, more complete and diverse system of public spaces, thus generating a quality atmosphere suitable for residents and visitors to the city alike.

\subsubsection{Proposed solution for the transformation and activation of the public spaces of the city centre}

The concept for public spaces in the centre of Varaždin is based on the principle of different subsystems whose completeness enchances the quality of life of both residents and visitors. In the centre of the city, 12 locations were detected ( 3 squares, 6 streets, and 3 courtyards), each with its own specifics, with proposed interventions that would mainly improve the public space of the city by applying "soft" measures. Specific interventions proposed for each location contribute to integration of public areas into the system and activate public spaces of the centre. The following interventions are planned: arrangement of "new" squares in the urban fabric and redistribution of square functions; arrangment of a new pedestrian street and installation of urban equipment in existing streets; introduction of "new" courtyards open for public use in the system of existing courtyards; redefinition of the existing park on the northeastern edge of the historic urban core; arrangement of a new children's playground; arrangement of new bicycle paths and construction of new bicycle pavilions; construction of a new underground public garage and removal of parking lots on the northern edge of the city centre; and new traffic regulation. Planned interventions in transport infrastructure can directly or indirectly contribute to sustainable urban mobility patterns, reduce total energy consumption, protect biodiversity, water resources and air quality, reduce the risk of disasters, improve the overall quality of public space forming convivial and safe environments, provide more comfortable housing, and guarantee the social inclusion and integration by using different transport subsystems. Additional landscape elements can contribute to enhanced biodiversity, improved air quality, and easier adaptation to climate changes. In addition, they can further creation of convivial environments, provide a peaceful environment for adequate housing, and encourage social integration.
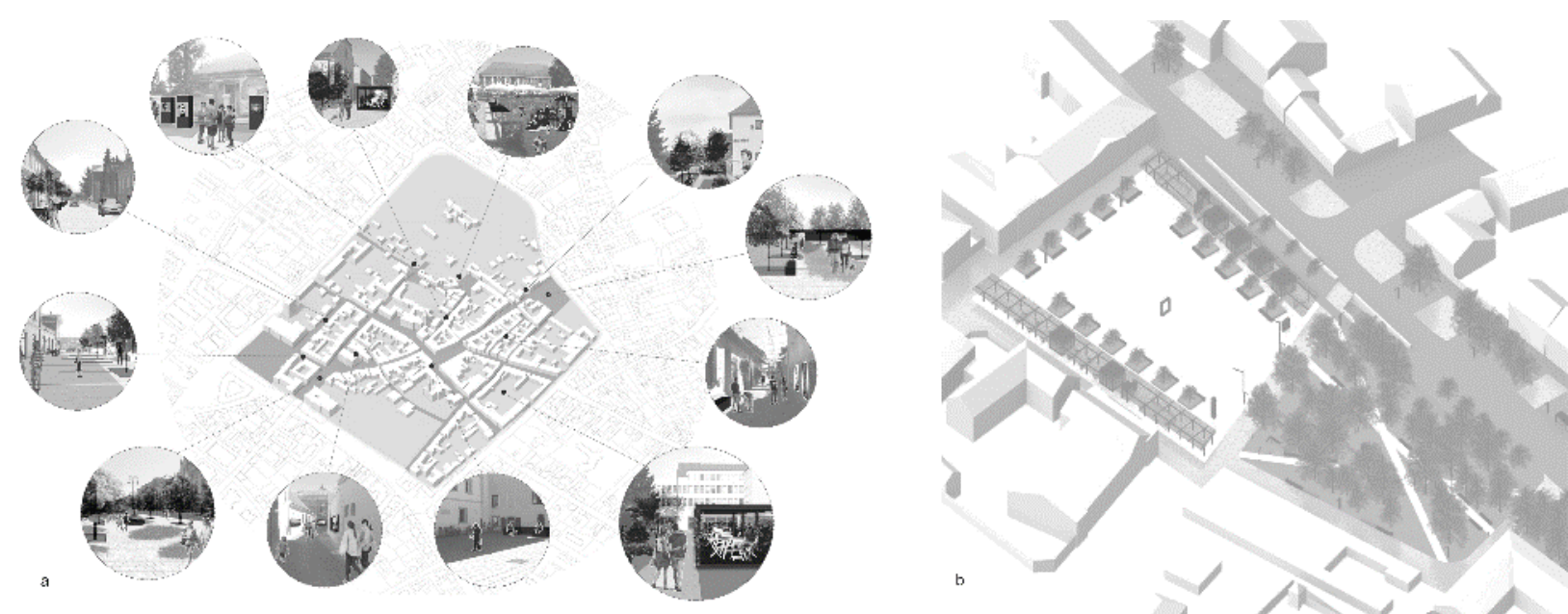

Figure 2: a) Interventions in the subsystems of the public spaces of the centre towards creation of a complete system; b) Ban Josip Jelačić Square and Park project (source: Marić, 2019). 
Special emphasis is given to the northeastern edge of the former historic fortifications, which has been recognized as a strong potential but also an area in need of extensive interventions. Ban Josip Jelačić Square and Park are conceived as a unique space of dual character. In the context of mobility, the proposal envisages construction of a two-floor underground garage in order to free the area of the square from the existing parking lot. The project envisages induction of the square area into the pedestrian zone of the centre and creation of new pedestrian paths, respecting historical routes. Two stretches of various facilities (flower shops, terraces, and pavilions for rent) were planned as a supplement to existing facilities to further activate public space. The pavilions with facilities on the perimeter of the square use PV panels to generate electricity. In the summer, the cooling of the pavilions is enabled by natural ventilation, the canopy, while the existing structure and the surrounding high vegetation serve as protection from excessive insolation. During the winter, the glass facade of the pavilions allows the passage of sunlight and thus contributes to heating of the interior. The proposal of new facilities in the city centre enables improvement of the public space through creating vibrant environments, enabling social integration, opening the opportunities for local employment, and deterring expansion of construction to greenfield areas, while the use of PV panels would additionally enable reduction of total energy consumption. In addition to the horticultural enrichment of the existing park and the preservation of the existing landscape elements, the perimeter of the square is planned with additional tree lines. In the northwestern part of the park, a children's playground and additional urban equipment is proposed, designed for the needs of the public space system of the centre of Varaždin. Installation of new urban equipment (benches, plant pots, flowerpots, refuse receptacles, info boards, sculptures, clocks) is planned to enhance social interaction and integration of different users. Additionally, it can contribute to the creation of a convivial, safe, and vibrant environment, and the accessibility of public space for different age groups, while use of plant pots contributes to protection and enhancement of biodiversity.

\subsection{Ivanić-Grad}

The town of Ivanić-Grad is located in the southeast of Zagreb County. The total area of the city is 17,357 ha, with 19 settlements with a total of 14,548 inhabitants. The central settlement of Ivanić-Grad with 9,379 inhabitants is a significant economic and cultural centre of the southeastern part of Zagreb County. The centre of the city covers the area of 12 ha (Table 1).

\subsubsection{Historical features}

Analysis of contemporary urban structure shows that the city centre has developed throughout history as two separate spatial units, namely the site of a former fortress and its suburb. Historical sources state that a wooden castle was built in the early $13^{\text {th }}$ century, while in the middle of the $16^{\text {th }}$ century a "novum fortalicium Iwanychensi" is mentioned. Towards the end of the $16^{\text {th }}$ century, a new bastion fortress was built on the site of the previous atypical square fortress. The fort was completed in 1606, and its construction was led by Viatana, Francesco Marmaro, and Alessandro Pasqualini (Žmegač, 1998; Žmegač, 2000). The compact structure of the suburbium (nowadays the Old Town) was formed nearby in the middle of a swamp on an artificial island on the extension of the Lonja River, south of the former fortress (nowadays a park). Historical sources mention that the settlement was fortified in 1570, with an earthen embankment, a water-filled moat, palisades, and a wooden bridge as a connection with the fortress. Suburbium was a trade and craft settlement, and to this day the urban matrix has almost completely preserved the historical layout of streets and squares created before the mid- $19^{\text {th }}$ century, and, to a lesser extent, the scale of construction (Mavar \& Tusun, 2011). 
As a result of changes in the geopolitical situation, the fortress lost its purpose; the army abandoned it in 1776, and the area of former bastion fortification was gradually transformed. In the first part of the $19^{\text {th }}$ century, bastions and the moat were levelled, and during the rest of the century public buildings were gradually built in their place, while in 1910 the city park was arranged in neoclassical and natural style by the Czech landscape architect Viteslav Durchanek. The transformation of bastion fortifications resulted in well-designed extension of the city core with new public spaces, which created a new urban quality, while the suburbium preserved its urban matrix and the possibility of new representative public spaces on its periphery (Figure 3a).
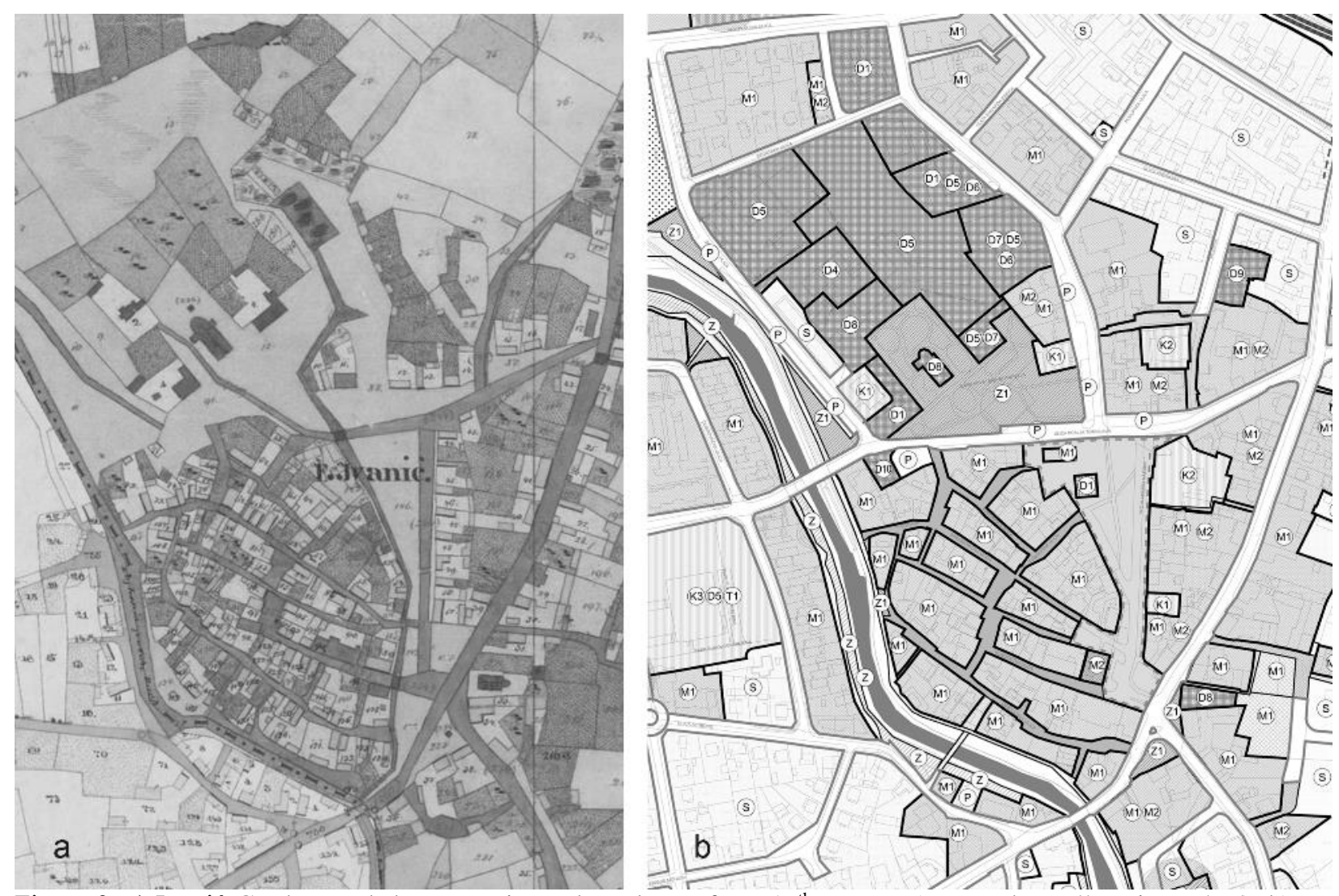

Figure 3: a) Ivanić-Grad on Habsburg Empire cadastral map from $19^{\text {th }}$ century (source: https://mapire.eu/en/); b) Urban Development Plan UPU - 4 for the area Ivanić-Grad, Donji Šarampov, and Jalševec Breški (2008) (source: Urbanistički plan uređenja UPU - 4 za područje Ivanić-Grad, Donji Šarampov i Jalševec Breški, 2018).

\subsubsection{Spatial planning documentation}

The cultural and historical ensemble of Ivanić-Grad has been enlisted in the Register of Cultural Assets, and according to the Urban Development Plan UPU - 4 for Ivanić-Grad, Donji Šarampov and Jalševec Breški area (2008) and its amendments (2009, 2012, 2014/2015, 2016, 2018), divided into two sub-units: the Zone of partial protection of historical structures (Zone $\mathrm{B}$ ), which includes the southern area, and the Buffer zone (Zone C), which refers to a part of the northern area. The entire city centre is included in protection zone of archaeological area, while only the suburbium is defined as historical urban core.

In the spatial planning documentation, the northern part of the subject area is intended mainly for public use, and in the southern part there is a public area categorized as a particularly valuable area - cultivated landscape. The southern part of the area, the former suburbium, is predominantly planned as mixed use. The transport infrastructure on the northern part of the area is planned for combined transport systems, while public spaces on the southern part are 
planned as car-pedestrian or exclusively pedestrian area (the main town square). Pedestrian promenades are planned along the Lonja River on both banks. Adjacent to King Tomislav Street, a public parking area with optional public multi-storey garage under the main square is planned (Figure 3b). In order to protect cultural and historical values, the plan proposes recultivation and integration of city squares, and integration of former fortress and Lonja River landscape with the park of Croatian Veterans.

\subsubsection{Problems of public space in the city centre}

The analysis of traffic infrastructure in the centre of Ivanić-Grad shows domination of automobile traffic over pedestrians. King Tomislav Street is a spatial barrier which divides central city area into two parts: the northern area of the former fortress and the southern area of the former suburbium. The historic structure of narrow streets without sidewalks in the Old Town (former suburbium) results in questionable safety of pedestrians. The main town square, east of suburbium, is separated from perimeter structure on the eastern part by a street and a stretch of parking area, creating a barrier to public facilities located in the square. The southern part of the square is subordinated to car traffic and is not suitable for pedestrians. In the city centre, parking lots are provided alongside roads in the northern part, while a large number of illegal parking lots alongside narrow streets of the former suburbium represent a further burden on the traffic system. South of the Park of Croatian Veterans, along King Tomislav Street, there is a stretch of parking lots preventing spatial connection of the park and the southern part of the centre.

The analysis of public spaces of the city centre shows intensive activities in articulation of public areas during past few years, especially the areas around public buildings and the promenade along the Lonja River which has not yet been connected with other public areas of the city centre. The analysis shows that the city centre has a landscaped area, namely a park on the north side of the scope, while the urban structure of the former suburbium with traditional buildings in a dilapidated condition lacks vegetation as well as city centre facilities. The city centre is active only a few days each year during public events, among which the Bučijada ("Pumpkin Fair") stands out. The analysis of the current situation of Ivanić-Grad centre underlines the need for planning public space of the city centre with priority given to pedestrian traffic, which would contribute to integration of historically divergent parts of the centre and creation of an environment that would enable stronger activation of the centre.

\subsubsection{Proposed solution for the transformation and activation of the public spaces of the city centre}

The concept of public spaces in the city centre is based on revival of its culture and history, and integration of public spaces. The project proposed that certain locations become info points, i.e. open-air museum stations. While walking through the centre, the pedestrian would learn about the history of the city and the importance of each location. The main town square is planned as the starting and ending point of the open-air museum where the visitor can recognize the importance of local events for the city through public space design. Traditional buildings in the former suburbium offer insight into the local way of life, while the site of former fair in the centre of Old Town is conceived as theme area dedicated to craftsmen and merchants. Public buildings located in the city park form a site where visitors can learn about the formation of the Ivanic fortress and its gradual destruction, the very event which resulted in the creation of the park itself. Recent history data can be found in Public Open University, the INA building, and the atomic shelter. Locations are connected by a pedestrian promenade with distinctive paving directing visitors through different ambiences. The Museum path is linked to new promenade along the Lonja River, thus connecting urban structure with landscape. The offer of various 
facilities in the city centre contributes to improvement of public space by creating vibrant environments, enabling social integration, opening the opportunities for local employment, and discouraging further expansion into greenfield areas.

In order to reduce traffic through the centre and to enable integration of the northern and southern parts, circular traffic scheme was proposed on the northern part, turning portion of King Tomislav Street into a car-pedestrian area. Streets of former suburbium are predominantly planned as car-pedestrian with pedestrian priority over private motorized traffic. Planned interventions in transport infrastructure can directly or indirectly contribute to sustainable urban mobility; reduction of total energy consumption; protection of biodiversity, water resources, and air quality; reduction of disaster risk; improvement of overall quality of public space forming convivial and safe environments; provision of more comfortable housing; and social inclusion by different transport subsystems usage.
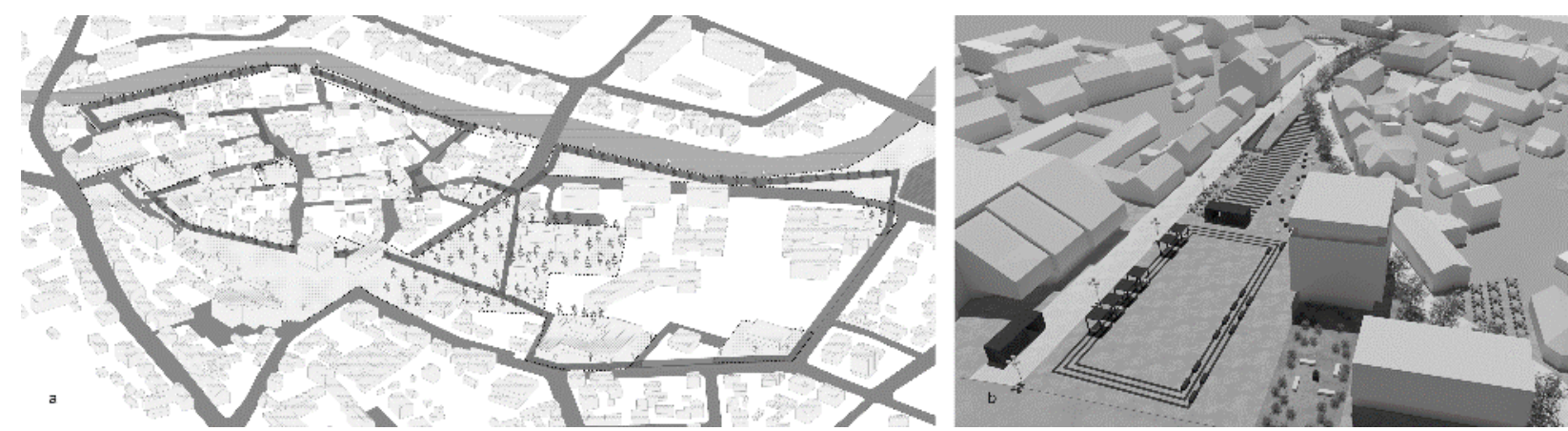

Figure 4: a) Integration of public spaces of the centre based on the concept of open-air museum; b) Vladimir Nazor Square project (source: Kunek, 2020).

Special attention is paid to irregular funnel-shaped main town square located in the southeastern part of the centre, due to its position in the urban matrix recognized as possible starting location for public space problem solving. Design concept of the main town square is based on two promenades placed circumferentially to the main north-south communication axis providing supply and connection of facilities and public areas. The square is divided into three zones: a large concert square in the north, a social square in the central zone planned for exhibitions and sales, and a small square in the south planned as a summer cinema. The abolition of the road on the east side of the square enables the integration of square and perimeter facilities. A pedestrian zone connected to public spaces of the former suburbium is also provided for. The problem of parking and traffic congestion of the centre is solved by an underground garage under the main square, with access from the south in order to free up as much space as possible for pedestrian use.

The project envisions green surface of the northwestern part of the square, and the western promenade with children's playground providing peaceful environment near the throng of the main town square. Landscaping can contribute to biodiversity enhancement, air quality improvement, easier adaptation to climate change, and to creation of convivial environments with provision of a peaceful setting for adequate housing and social integration. Each zone of the square has urban equipment (benches, refuse receptacles, display stands, sculpture) providing different use scenarios, social interaction, and user integration. Implementation of planned urban equipment can also contribute to creation of a convivial, safe and vibrant environment, and accessibility of public space for different age groups. 


\section{Research results and discussion}

The area of the central settlement of Varaždin occupies $46.62 \%$ of total city area. The considered centre of Varaždin covers $1.37 \%$ of the central settlement, while the central settlement is home to $85 \%$ of total population of Varaždin. Ratio of number of inhabitants and the area of the city centre shows $9.54 \mathrm{~m}^{2}$ of the centre per one inhabitant of the central settlement and $8.89 \mathrm{~m}^{2}$ of the centre per one inhabitant of the city of Varaždin. The area of the central settlement of Ivanić-Grad occupies $13 \%$ of total city area. The centre of Ivanić-Grad covers $0.52 \%$ of the central settlement, while $64 \%$ of total population of Ivanić-Grad live in the central settlement. Ratio of number of inhabitants and the area of the city centre shows $12.79 \mathrm{~m}^{2}$ of the centre per one inhabitant of the central settlement and $8.25 \mathrm{~m}^{2}$ of the centre per one inhabitant of the city of Ivanić-Grad.

\subsection{First level of consideration - city centre}

The analysis shows that the project envisages reduction of total road length in the centre of Varaždin by $10.25 \%$. The organization of stationary traffic in the city centre has been changed by abolition of $25.18 \%$ of parking lots (located along roads or as separate areas) and construction of new underground garage with 161 parking spaces on the northeastern edge of the centre. The length of bicycle paths in the city centre has increased by $400.65 \%$. One new bicycle rack and 3 new bicycle pavilions are planned. The analysis shows that pedestrian zone in the city centre has been expanded by $25.36 \%$ and makes up $12.12 \%$ of total area of the centre (Table 2 and Figure 5).

Table 2: Comparative overview of first level consideration indicators - traffic.

\begin{tabular}{|c|c|c|c|c|}
\hline \multirow{2}{*}{$\begin{array}{l}\text { First level consideration } \\
\text { Traffic }\end{array}$} & \multicolumn{2}{|c|}{ Varaždin } & \multicolumn{2}{|c|}{ Ivanić-grad } \\
\hline & Before & After & Before & After \\
\hline Road (m) & $4,066.48$ & $3,649.38$ & $2,703.39$ & $1,917.09$ \\
\hline Parking $\left(\mathrm{m}^{2}\right)$ & $13,524.04$ & $10,118.59$ & $7,316.84$ & $3,742.22$ \\
\hline $\begin{array}{l}\text { Public underground garage (number and } \\
\text { total capacity) }\end{array}$ & $1(446)$ & $2(607)$ & - & $1(200)$ \\
\hline Car-pedestrian area (m) & - & - & 87.30 & 977.43 \\
\hline Pedestrian zone $\left(\mathrm{m}^{2}\right)$ & $36,728.54$ & $46,044.78$ & $4,109.03$ & $9,409.34$ \\
\hline Pedestrian path (m) & - & - & 689.55 & $2,624.45$ \\
\hline Bicycle path (m) & 655.85 & $3,283.57$ & 689.55 & $1,063.26$ \\
\hline Bicycle rack (BR) / Bicycle pavilion (BP) & $7 \mathrm{SB}$ & $8 \mathrm{SB}+3 \mathrm{~PB}$ & $9 \mathrm{SB}$ & $11 \mathrm{SB}$ \\
\hline
\end{tabular}

Green public areas in the centre were increased by $0.44 \%$ due to green courtyards opening for public. The total tree line length in the city centre has been increased by $64.92 \%$. Total of $48.92 \%$ of newly planned pedestrian zone (squares, streets, and public courtyards) is activated by installation of new urban equipment (Table 3 and Figure 5) Proposed solution offers new facilities in public spaces of the centre of Varaždin, distributed over area of the first level of analysis. Arrangement of new children's playground and renovation of existing one is planned, thus providing social interaction for the youngest. New areas for catering facilities (cafe terraces) are opened, aiming at further activation of the space of the city centre, as well as installation of small new pavilions for florists and cafes, bicycle storage, etc. (Table 4 and Figure 5). 

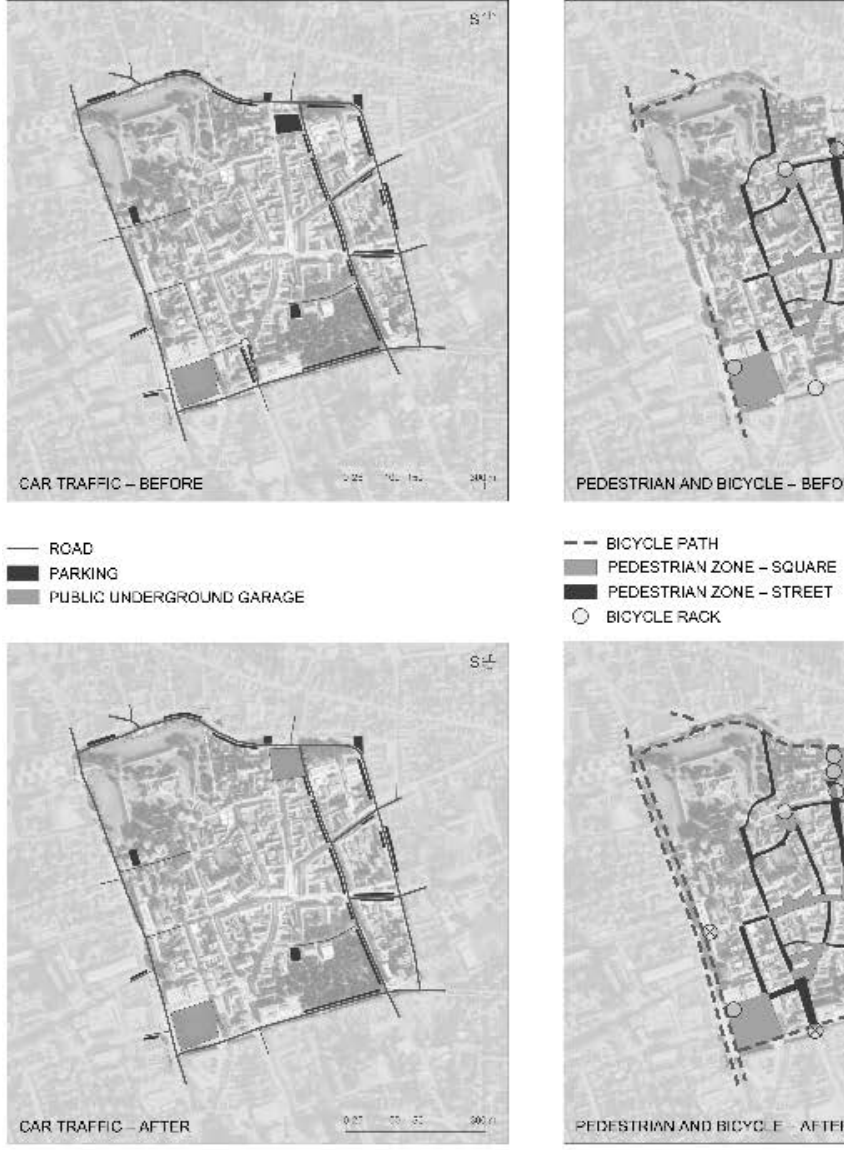

$$
\begin{aligned}
& \text { - ROAD } \\
& \text { PARKING } \\
& \text { PUBLIC UNDERGROUND GARAGE }
\end{aligned}
$$
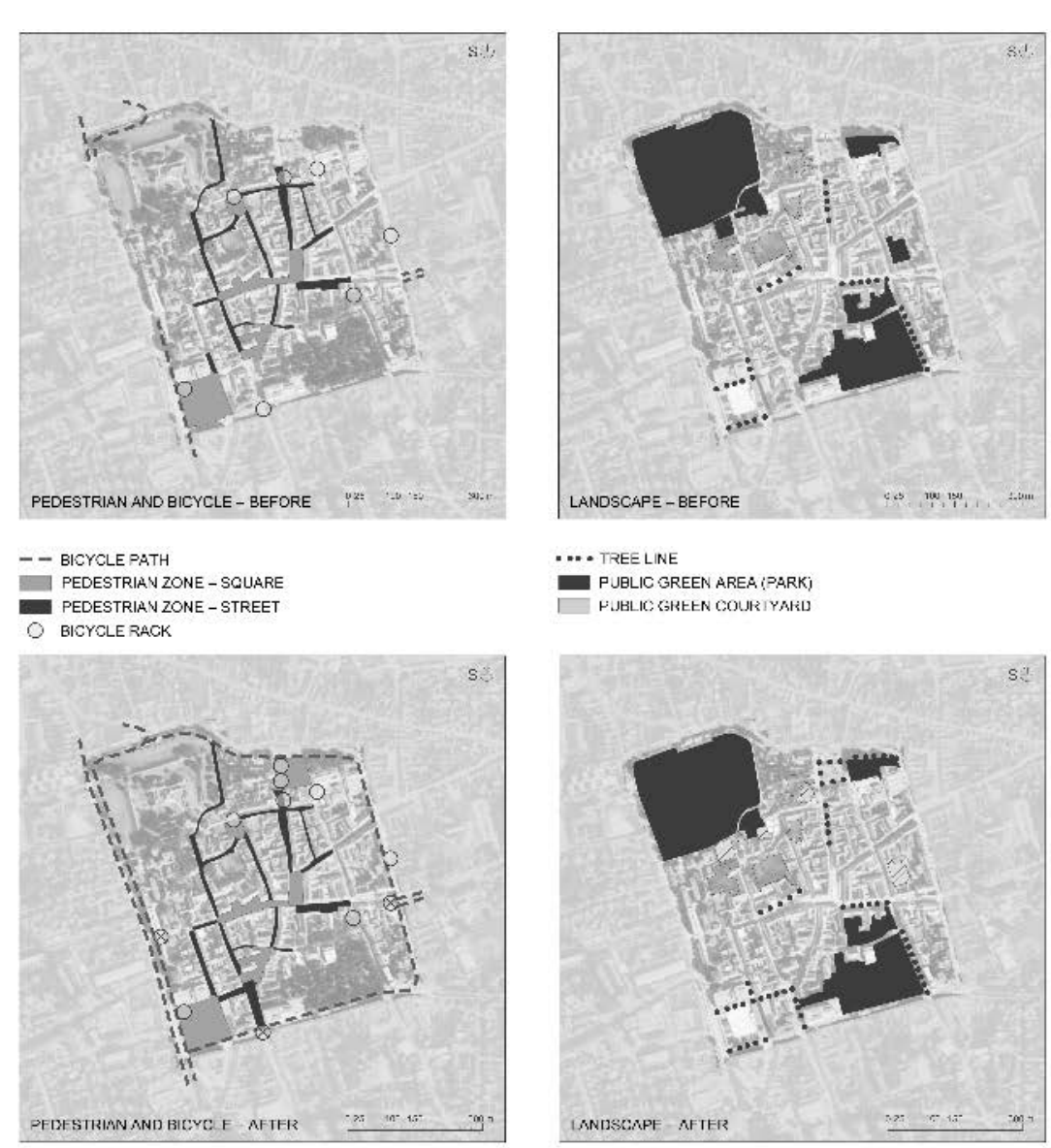

$$
\begin{aligned}
& \text { - BICYCLE PATH } \\
& \text { PLDESTRIANZONE SOUARE } \\
& \text { PEDESTRIANZONE STREET } \\
& \text { BICYCLERACK } \\
& \otimes \text { BICYCLE PAVILION }
\end{aligned}
$$

PJELIC GREEN AREA IPARK

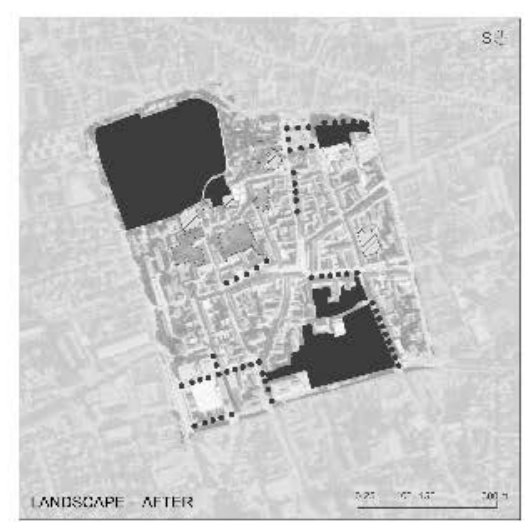

IANISCMPE - MFTE

.... TREE LINE

PUBLIC GREEN AREA (PARRK)

PUBLIC GREEN COURTYARO

Z2 GREEN AREA WITH NEW PUBUG USE

Figure 5: Varaždin - first level consideration indicators (illustration: authors).

Table 3: Comparative overview of first level consideration indicators - landscape.

\begin{tabular}{lrrrr}
\hline First level consideration & \multicolumn{2}{c}{ Varaždin } & \multicolumn{2}{c}{ Ivanić-grad } \\
\hline Landscape & Before & \multicolumn{1}{c}{ After } & \multicolumn{1}{l}{ Before } & \multicolumn{1}{c}{ After } \\
\hline Public green areas (i.e., park) of the city & $93,634.73$ & $89,445.25$ & $19,119.49$ & $20,120.03$ \\
centre $\left(\mathrm{m}^{2}\right)$ & & & & \\
Green courtyards in public use $\left(\mathrm{m}^{2}\right)$ & $10,362.38$ & $15,009.48$ & - & $2,045.89$ \\
Tree line $(\mathrm{m})$ & 639.77 & $1,055.09$ & 282.95 & 406.09 \\
\hline
\end{tabular}

The analysis shows that proposed solution reduces total road length in the centre of Ivanić-Grad by $29.08 \%$. The share of areas intended for car-pedestrian traffic in the city centre is increased by $1019.62 \%$. The organization of stationary traffic in the city centre has been changed in a way that $48.85 \%$ of parking lots (alongside roads or as separate parking areas) have been abolished, and the construction of an underground garage with 200 parking spaces on the edge of the centre has been proposed. The length of bicycle paths in the town centre has increased by $54.19 \%$. Two new parking lots for cyclists are planned, an increase of $22.22 \%$. The analysis shows that the main pedestrian area in the town centre has been increased by $128.99 \%$, with total length of 2,624.45 m of pedestrian path through the centre, which enables activation of existing facilities and landscape area as well as opening new green areas for public use (Table 2 and Figure 6). 

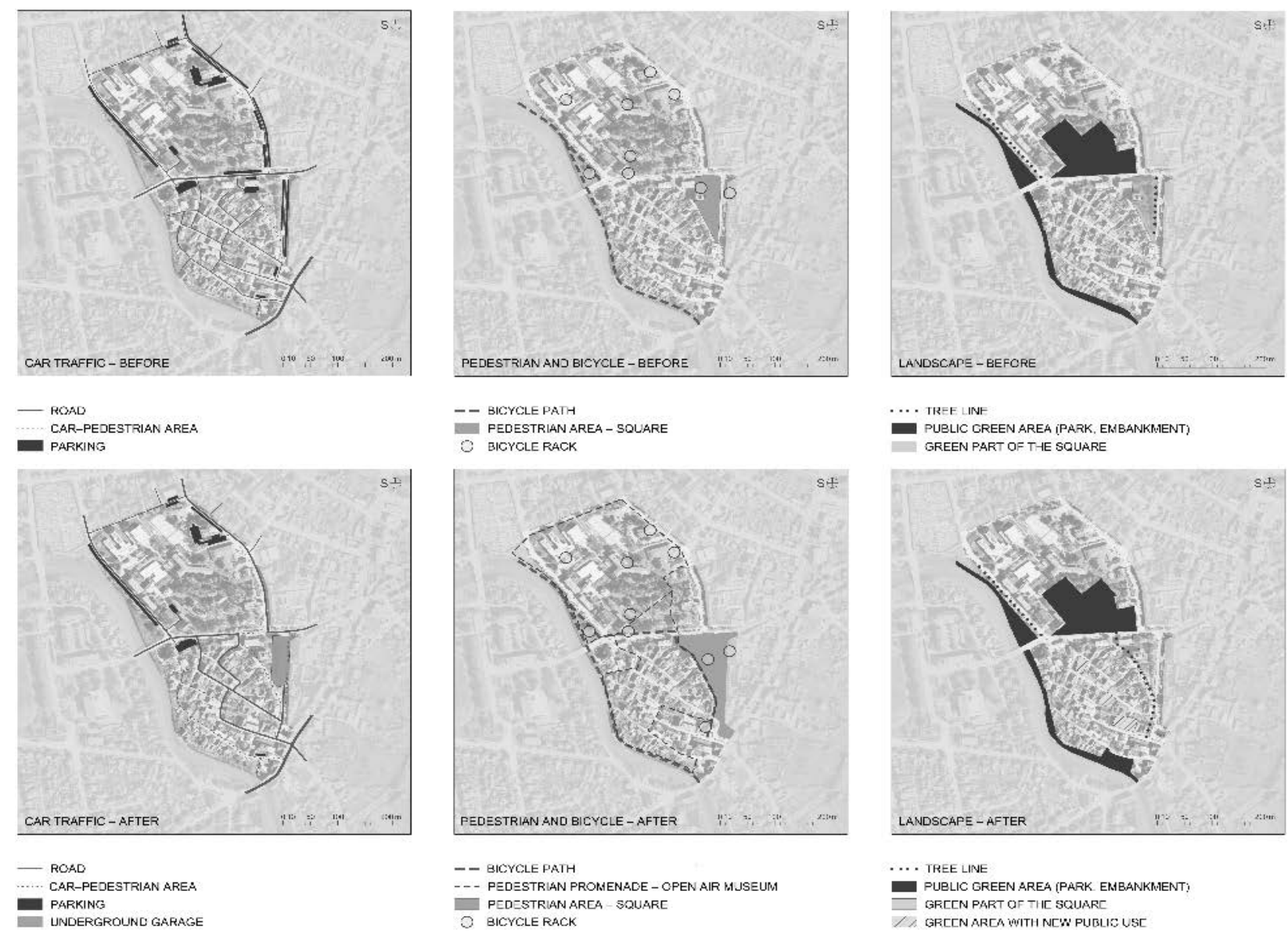

-- BICYCLE PATH
PEDESTRIAN AREA - SOUARE
BICYCLE RACK

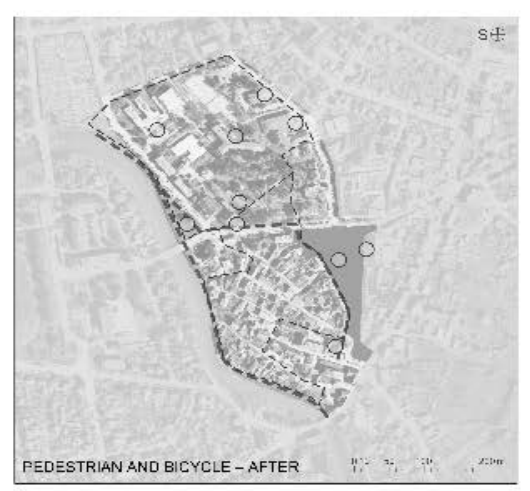

... TREF LINF
PUBLIC CREEN AREA (PARK, EMBAANKMENT)

G GREEN PART OF THE SqUARE

- EICYCLE PATH

--- PEDESTRLAN PRONENADE - OPEN AIR MUSEUMM

- PEDEstrLAN AREA - squARE

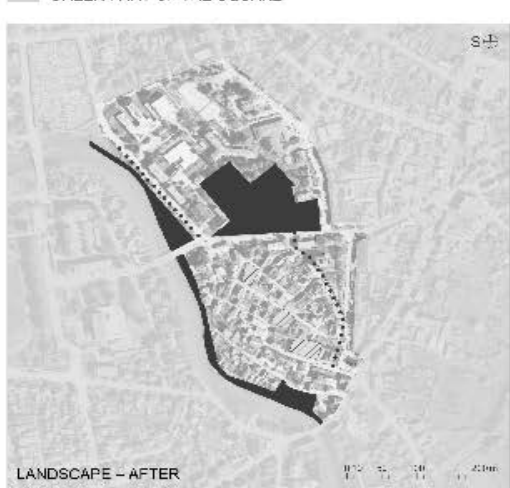

LANDSCAPE - AFTER

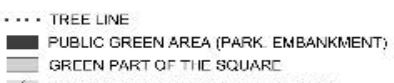

PUELIC GREEN AREA (PARK. E
GRECN PART OF TIIL SQUARC V.. GRCLN ARLA WITH NCW PUBLL USE

Figure 6: Ivanić-Grad - first level consideration indicators (illustration: authors).

Total green area of the centre in public use (which, in addition to parks and embankments, includes green courtyards in public use) has been increased by $15.93 \%$, while total tree line length has increased by $43.52 \%$ (Table 3 and Figure 6), New facilities in public spaces planned in the centre of the town are distributed over the area of the first level of analysis, with new children's playground next to the pedestrian zone, new catering facilities area (cafe terraces), an amphitheatre in the southern part of the town square, as well as installation of educational info panels in open-air museum stations throughout the centre (Table 4 and Figure 6).

Table 4: Comparative overview of first level consideration indicators - facilities.

\begin{tabular}{|c|c|c|c|c|}
\hline \multirow{2}{*}{$\begin{array}{l}\text { First level consideration } \\
\text { Facilities }\end{array}$} & \multicolumn{2}{|c|}{ Varaždin } & \multicolumn{2}{|c|}{ Ivanić-grad } \\
\hline & Before & After & Before & After \\
\hline Children's playground & + & $\begin{array}{c}+ \\
\text { Larger and } \\
\text { newly } \\
\text { arranged }\end{array}$ & + & $\begin{array}{c}+ \\
\text { Newly } \\
\text { arranged }\end{array}$ \\
\hline Terraces of cafes on the streets and squares & + & + & + & + \\
\hline Florists and pavilions & + & + & - & - \\
\hline Bicycle pavilion & - & + & - & - \\
\hline Amphitheatre & - & - & + & $\begin{array}{c}+ \\
\text { Newly built }\end{array}$ \\
\hline
\end{tabular}

The results of analysis in both case studies at the first level show significant reductions of areas used by motor vehicles (roads and parking lots), increase of exclusively pedestrian area, as well as significant increase of area for cyclists. In both cases underground garages are planned to free up space for pedestrian use. Results show an increase in percentage of green public areas 
in both cases (achieved by opening courtyards for public use) and significant increase of tree line length. At the first level, in both cases various facilities that contribute to quality of life of residents and enable social interaction are planned. Implementation of new facilities for public use and installation of urban equipment has led to activation of significant areas in city centre. Activation of city centre in Varaždin is achieved by installation of urban equipment in public space (streets, squares, and courtyards), while in Ivanić-Grad vibrancy of the centre and dynamic of use is achieved by public facilities implemented in the peripheral suprastructure and ecostructure.

\subsection{Second level of consideration - selected public area}

Ban Josip Jelačić Square and Park, located in the northeastern part of the centre of Varaždin, cover $3.68 \%$ of the analysed centre area. The analysis shows reduction of parking area by 83.13\% and reduction of area intended exclusively for motor traffic by $51.94 \%$. An underground public garage with 161 parking spaces, bicycle path in the length of $227.47 \mathrm{~m}$, and new bicycle pavilion are planned in the square. Pedestrian area of the square is increased by $85.01 \%$, the share of green area is reduced by $4.64 \%$, and significant new tree lines were planned with an increase of 322.64\%. Public facilities (trade, service, and leisure) occupy a significant share of the square and park (30.13\%) in which new urban equipment is also installed (Figure 7 and Table 5).
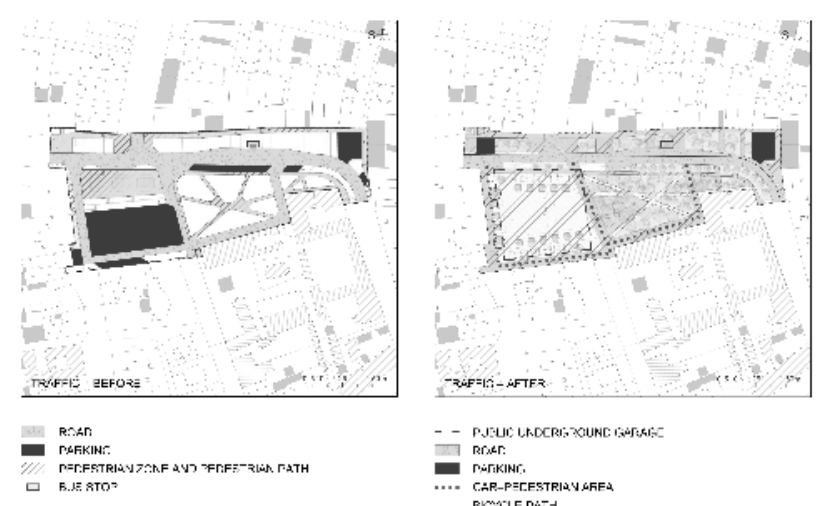

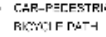

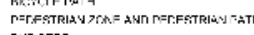
R.I:STOP
RIMTIF RAOS

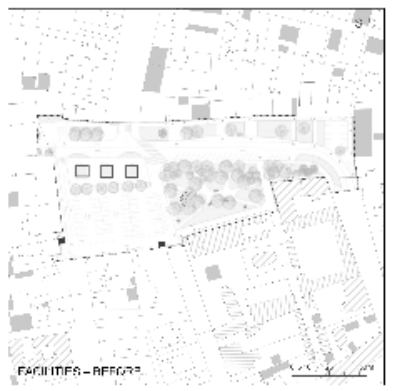

-

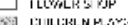
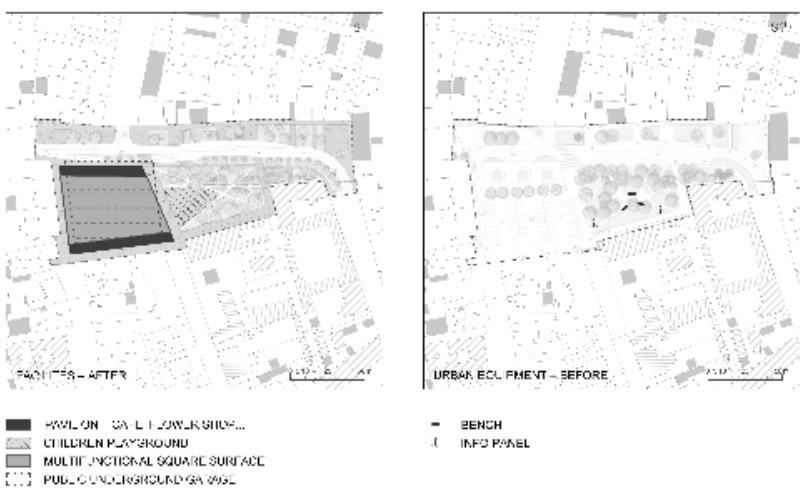

- IFEREH
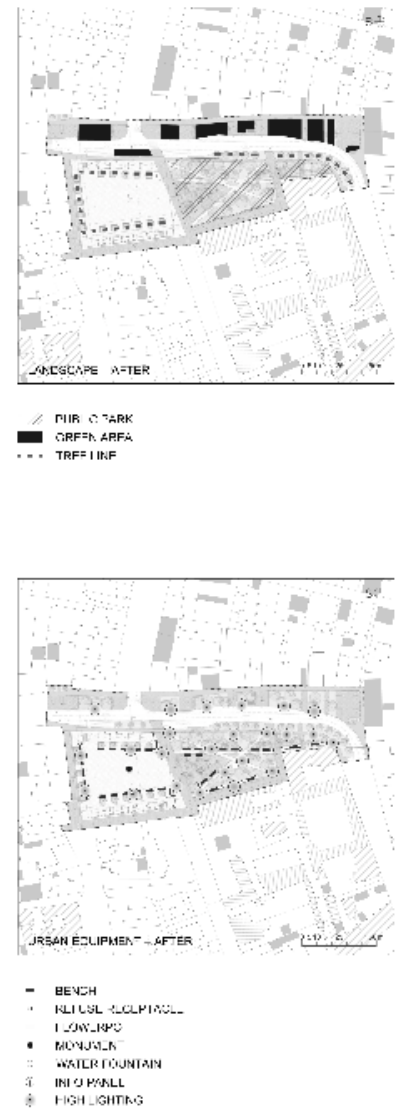

Figure 7: Varaždin, Ban Josip Jelačić Square and Park - second level consideration (illustration: authors). 

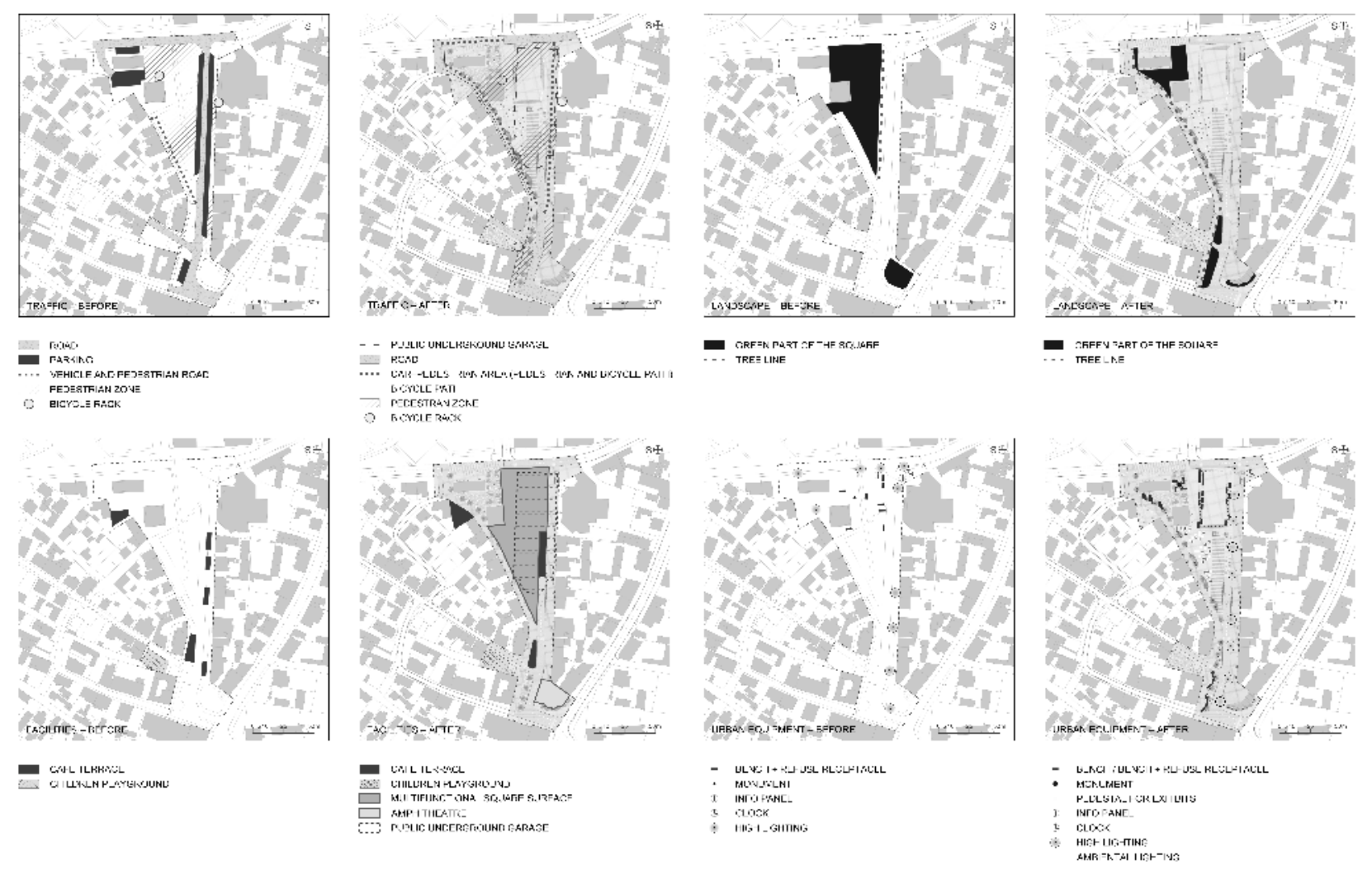

Figure 8: Ivanić-Grad, Vladimir Nazor Square - second level consideration (illustration: authors).

Vladimir Nazor Square is located on the eastern edge of the centre of Ivanić-Grad, covering $10 \%$ of centre area. The analysis shows planned reduction of the area intended for parking on the subject area by $100 \%$ and reduction of area intended exclusively for motor traffic by $38.92 \%$. An underground public garage with 200 parking spaces is planned, and the share of pedestrian areas of the square is increased by $73.63 \%$. The project envisages a green promenade with $231.99 \mathrm{~m}$ long bicycle path along the edge of the square as connection of central square with bicycle path along the Lonja River. The project reduced the share of green part of the square by $96.31 \%$, but new tree lines were planned which represents an increase of $110.65 \%$. Facilities (trade and service) occupy $39.66 \%$ of total square surface on which installation of new urban equipment and multifunctional pedestals for various public events is planned (Figure 8 and Table 5).

Table 5: Comparative overview of indicators on the second level consideration.

\begin{tabular}{|c|c|c|c|c|}
\hline Second level of consideration & \multicolumn{2}{|c|}{ Varaždin } & \multicolumn{2}{|c|}{ Ivanić-grad } \\
\hline Traffic & Before & After & Before & After \\
\hline Parking $\left(\mathrm{m}^{2}\right)$ & $2,609.29$ & 439.97 & $1,596.00$ & 0 \\
\hline $\operatorname{Road}\left(\mathrm{m}^{2}\right)$ & 3,996.28 & $1,920.44$ & $2,761.31$ & $1,686.58$ \\
\hline $\begin{array}{l}\text { Capacity of public underground garage } \\
\text { (PS) }\end{array}$ & - & 161 & - & 200 \\
\hline Car-pedestrian area $\left(\mathrm{m}^{2}\right)$ & - & 310.21 & 84.9 & 335.51 \\
\hline Pedestrian zone + pedestrian path $\left(\mathrm{m}^{2}\right)$ & $3,238.77$ & $5,992.05$ & $5,305.94$ & $9,212.81$ \\
\hline Bicycle path (m) & - & 227.47 & - & 231.99 \\
\hline $\begin{array}{l}\text { Bicycle rack (BR) / Bicycle pavilion } \\
\text { (BP) }\end{array}$ & - & 2 & 2 & 3 \\
\hline \multicolumn{5}{|l|}{ LANDSCAPE } \\
\hline Public green areas (i.e. park) $\left(\mathrm{m}^{2}\right)$ & $2,941.68$ & $2,941.68$ & - & - \\
\hline Green area of the square $\left(\mathrm{m}^{2}\right)$ & $1,307.25$ & $1,246.59$ & $3,191.83$ & 117.69 \\
\hline Tree line $(\mathrm{m})$ & 54.01 & 228.27 & 107.15 & 225.72 \\
\hline
\end{tabular}




\begin{tabular}{lrrrr}
\hline Public underground garage $\left(\mathrm{m}^{2}\right)$ & - & $\begin{array}{r}3,357.77 \\
\text { (per floor) }\end{array}$ & - & $\begin{array}{r}3,080.16 \\
\text { (per floor) }\end{array}$ \\
Multifunctional square surface $\left(\mathrm{m}^{2}\right)$ & - & $2,669.02$ & - & $3,487.53$ \\
Amphitheatre & - & - & - & 433.22 \\
Pavilion (flower shop, cafe, etc.) & 184.77 & 866.41 & - & - \\
Cafe terrace $\left(\mathrm{m}^{2}\right)$ & 31.62 & - & 495.26 & 573.17 \\
Children's playground $\left(\mathrm{m}^{2}\right)$ & 76.09 & 550.24 & 265.77 & 265.77 \\
\hline Urban equipment & & & & \\
\hline Bench (pcs.) & 3 & 30 & 8 & 33 \\
Refuse receptacle (pcs.) & 10 & 11 & 11 & 15 \\
Monument (pcs.) & - & 1 & 1 & 1 \\
Pedestal for exhibits (pcs.) & - & - & - & 37 \\
Flowerpot (pcs.) & - & 6 & - & - \\
Water fountain (pcs.) & - & 1 & - & - \\
Info panel (pcs.) & 2 & 1 & 2 & 1 \\
Clock (pcs.) & - & 1 & 1 & 1 \\
High lighting (pcs.) & $19+6$ & $24+6$ & 10 & 9 \\
Ambient lighting (m) & - & - & - & 305,66 \\
\hline
\end{tabular}

The results of both case studies analysis at the second level, the selected public area, show significant reductions of area used by motor vehicles and almost complete abolition of parking areas. Furthermore, in selected public areas, there is a significant increase of areas used exclusively by pedestrians. In addition, the introduction of bicycle paths on subject areas as connection with wider spatial context is emphasized. In both cases, underground garages were planned to free up the square area for introduction of new facilities. The results show decrease in green areas of public space in both selected examples (especially in Ivanić-Grad) and increase of tree line length (especially in Varaždin - over 320\%). In both examples, the construction and arrangement of various facilities and installation of urban equipment is planned, which provides for spatial activation, enables social interaction, and contributes to overall quality of life in the city.

\section{Conclusion}

The historical significance of the town or city and urban structure morphology significantly conditioned proposed interventions and influenced the concept of public space design, encouraging its liveability. The planned transformation of public spaces in selected city centres takes into account current spatial planning documentation in which various sustainability elements were recognized (for instance mixed use, garages on the outskirts of city centres, destimulation or restriction of car traffic by introducing car-pedestrian or exclusively pedestrian areas, adding horticultural elements in public spaces, etc.). Therefore the plans propose new solutions which emphasize the importance and characteristics of sustainability in order to solve existing problems of the centre. Owing to the large number of different public areas of pedestrian zone (streets, squares, courtyards, parks, etc.), the system of public spaces in Varaždin enables the emphasis on specific features of individual elements of the system and their complementarity in the wider spatial context. The central public space in the smaller town of Ivanić-Grad combines different spatial and functional components of public space arrangement, thus giving the public space hybrid features. Combined elements of the square, street, and courtyard create multifunctional spatial features, daily, weekly, monthly, and yearly enhancing its liveliness which significantly contributes to social integration and quality of life. Two approaches to public space activation were detected during research. The first approach uses elements of urban equipment in the public area as activators of dynamics, and the second approach uses the implementation of public facilities in the peripheral suprastructure and 
ecostructure of public space to dynamize the use of the city centre. The reasons for different approaches are different scale of public space in the urban structure and the possibilities provided by the peripheral suprastructure and ecostructure (Figure 9a and 9b).
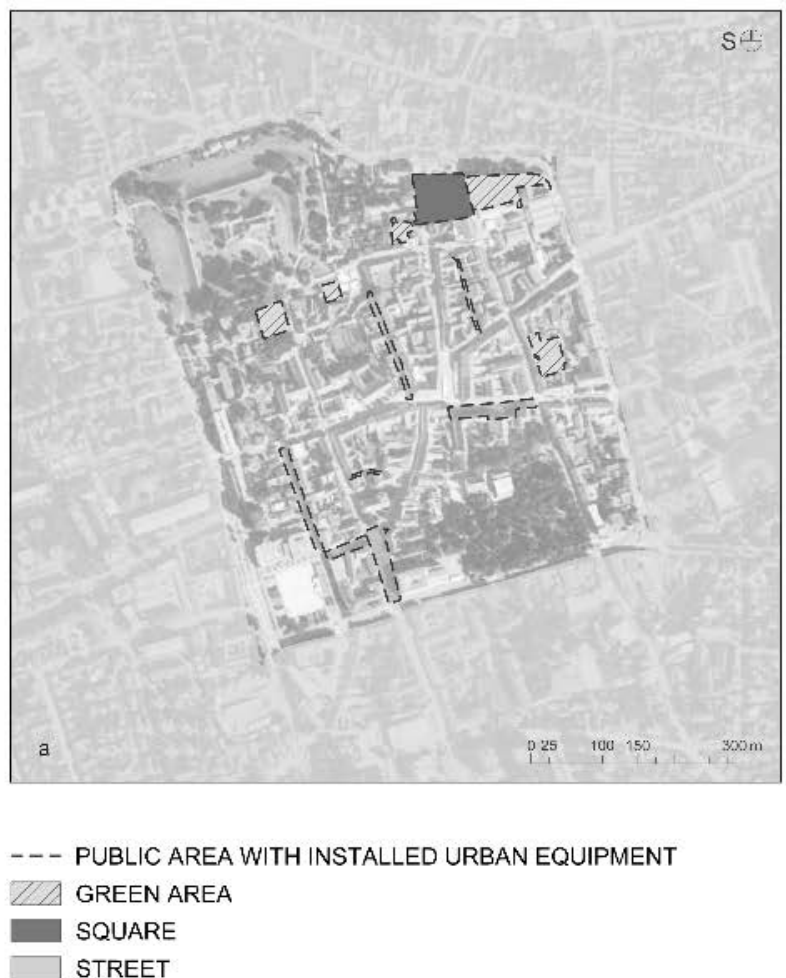
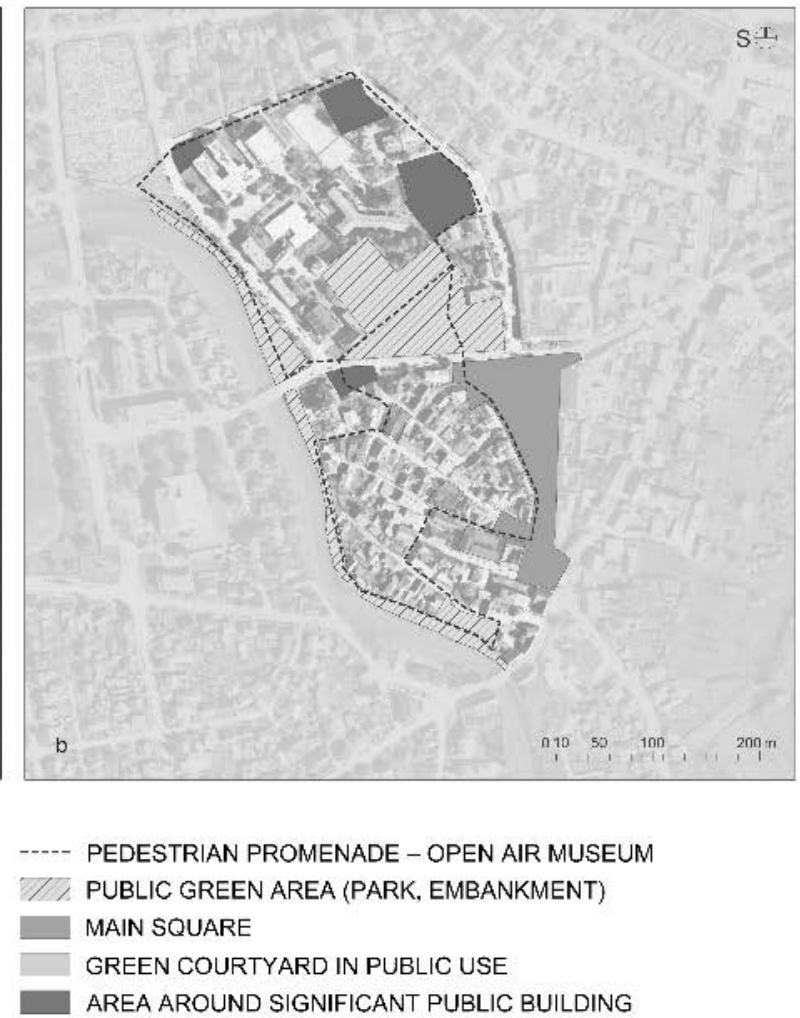

Figure 9: Comparative overview of the activation of public spaces in the centre of Varaždin and Ivanić-Grad: a) Varaždin; b) Ivanić-Grad (illustration: authors).

Table 6: Relation between analysed topics on both consideration levels and principles of sustainable development from the Basque Declaration.

\begin{tabular}{lcc}
\hline $\begin{array}{l}\text { Principles of sustainable development } \\
\text { from the Basque Declaration }\end{array}$ & Varaždin & Ivanić-grad \\
\hline
\end{tabular}

\begin{tabular}{|c|c|c|c|c|c|c|c|c|}
\hline & 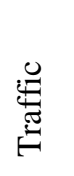 & 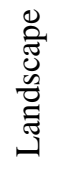 & 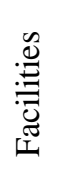 & 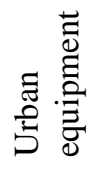 & 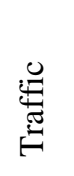 & 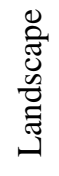 & 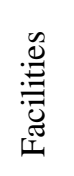 & 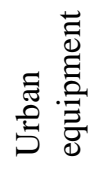 \\
\hline $\begin{array}{l}\text { Decarbonize our energy systems and } \\
\text { reduce total energy consumption }\end{array}$ & + & & + & & + & & & \\
\hline $\begin{array}{l}\text { Create sustainable urban mobility } \\
\text { patterns and accessibility for all }\end{array}$ & + & & & + & + & & & + \\
\hline $\begin{array}{l}\text { Protect and enhance biodiversity and } \\
\text { ecosystem services }\end{array}$ & + & + & & + & + & + & & \\
\hline $\begin{array}{l}\text { Reduce the use of greenfield land and } \\
\text { natural space }\end{array}$ & & & + & & & & + & \\
\hline $\begin{array}{l}\text { Protect water resources, water, and air } \\
\text { quality }\end{array}$ & + & + & & & + & + & & \\
\hline $\begin{array}{l}\text { Adapt to climate change and reduce } \\
\text { the risk of disasters }\end{array}$ & + & + & & & + & + & & \\
\hline $\begin{array}{l}\text { Improve public space to create } \\
\text { convivial, safe, and vibrant } \\
\text { environments }\end{array}$ & + & + & + & + & + & + & + & + \\
\hline
\end{tabular}


Provide sufficient and adequate housing for all

Guarantee social inclusion and integration of all parts of society

Strengthen local economies and local

employment opportunities

Regarding the projects of public space transformation in the centre of Varaždin and IvanićGrad in the context of sustainability and sustainable development, we conclude that they contribute to sustainability on the local level because both projects are in accord with all ten principles of sustainable development. Each of the topics covered contributes to at least three principles of sustainability (facilities), and the topic of traffic stands out since it contributes to as many as eight of ten principles of sustainability set out in the Basque Declaration (Table 6).

The research shows that all four topics covered (traffic, landscape, facilities, and urban equipment) contribute to the principle of Improving public spaces and creating a hospitable, safe, and vibrant environment and the principle of Ensuring social inclusion and integration of all parts of society.

We can conclude that planned activities of transformation and contemporary design of public spaces on the local level have multiple positive effects in the wider spatial context of the city, thus positively contributing to the global issue of sustainability.

\section{Lea Petrović Krajnik, University of Zagreb, Faculty of Architecture, Zagreb, Croatia (lea.petrovic@arhitekt.hr)}

Damir Krajnik, University of Zagreb, Faculty of Architecture, Zagreb, Croatia (damir.krajnik@arhitekt.hr)

Lea Kunek, Ivanić-Grad, Croatia (kunek.lea@gmail.com)

\section{References}

Aalborg Charter (1994) Available at: https://sustainablecities.eu/the-aalborg-charter/ (accessed 2 Nov. 2020).

Aalborg Commitments (2004) Available at: https://sustainablecities.eu/the-aalborg-commitments/ (accessed 2 Nov. 2020).

Aman, M., Waheed, A., Naeem, M. A. \& Shah, S. A. A. (2019) Implementing the living streets concept by transforming streets in the central business district of Peshawar, Pakistan. Urbani izziv, 30(1), pp. 75-86. DOI: 10.5379/urbani-izziv-en-2019-30-01-001

Basque Declaration (2016) Available at: https://sustainablecities.eu/about-the-basque-declaration/ (accessed 2 Nov. 2020)

Carmona, M. (2010) Public places, urban spaces: The dimensions of urban design. Abingdon, UK, Routledge.

European Commission (2004) Reclaiming city streets for people: Chaos or quality of life? Brussels, DirectorateGeneral for the Environment, EC. Available at: https://op.europa.eu/hr/publication-detail//publication/94a8a003-be86-467a-9a85-63a5d52bf7ae (accessed 5 Nov. 2020).

Farr, D. (2011) Sustainable urbanism: Urban design with nature. Hoboken, NJ, John Wiley \& Sons.

Gehl, J. (2011) Life between buildings: Using public space. Washington, DC, Island Press.

Gehl, J. (2013) Cities for people. Washington, DC, Island Press.

Internet 1: https://mapire.eu/en/ (accessed 18 Nov. 2020).

Krajnik, D. (2007) Urbanistička preobrazba bastionskih utvrđenja. Doctoral thesis. Zagreb, University of Zagreb, Faculty of Architecture.

Krajnik, D. \& Obad Šćitaroci, M. (2007) Preobrazba bastionskih utvrđenja grada Varaždina. Prostor, 15(2), pp. 180-193.

Kunek, L. (2020) Urban planning and architectural proposal for public spaces in the centre of Ivanić-Grad. Master's thesis. Zagreb, University of Zagreb, Faculty of Architecture. 
Maretić, M. (1996) Gradski centri. Zagreb, Školska knjiga.

Marić, T. (2019) Urban planning and architectural proposal for public spaces in Varaždin city centre. Master's thesis. Zagreb, University of Zagreb, Faculty of Architecture.

Miller, H. J., Witlox, F. \& Tribby, C. P. (2013) Developing context-sensitive livability indicators for transportation planning: A measurement framework. Journal of Transport Geography, 26, pp. 51-64. DOI: 10.1016/j.jtrangeo.2012.08.007

Petrović Krajnik, L., Obad Š́́itaroci, M. \& Dundović, B. (2013) Perivojna arhitektura projekta EXPO’98: Čimbenik preobrazbe istočnog obalnog područja Lisabona. Prostor, 21(1), pp. 128-139.

Pojani, D. \& Stead, D. (2015) Sustainable urban transport in the developing world: Beyond megacities. Sustainability, 7(6), pp. 7784-7805. DOI: 10.3390/su7067784

Polat, S. \& Tümer Yildiz, H. Ö. (2019) Community engagement in developing urban design guidance for heritage sites: The case of Bursa, Turkey. Urbani izziv, 30(2), pp. 70-84. DOI: 10.5379/urbani-izziv-en-2019-3002-001

Prostorni plan uređenja grada Ivanić-Grada (2017) Službeni glasnik Grada Ivanić-Grada, 3/17, Ivanić-Grad.

Prostorni plan uređenja grada Varaždina (2005) Službeni vjesnik Grada Varaždina, 2/05, Varaždin.

Urbanistički plan uređenja UPU - 4 za područje Ivanić-Grad, Donji Šarampov i Jalševec Breški (2018) Službeni glasnik Grada Ivanić-Grada, 13/08, 05/09, 01/12, 06/14, 03/15, 05/18, 06/18, Ivanić-Grad.

Urbanistički plan uređenja povijesne jezgre grada Varaždina (2019) Službeni glasnik Grada Varaždina, 7/19, Varaždin.

Žmegač, A. (1998) Novootkriveni nacrti za utvrdu Ivanić (1597-8). Peristil: zbornik radova za povijest umjetnosti, 41(1), pp. 35-42.

Žmegač, A. (2000) Bastioni kontinentalne Hrvatske: prilog poznavanju fortifikacijskog graditeljstva u Hrvatskoj od 16. do 18. stoljeća. Zagreb, Golden Marketing \& Institut za povijest umjetnosti.

Mavar, Z. \& Tusun, M. (2011) Konzervatorska istraživanja kao podloga za razvojne planove Ivanić-Grada. In: Božić, N. \& Dumbović Bilušić, B. (eds.) Modeli upravljanja procesima obnove i razvoja povijesnih gradova / primjer Ivanić-Grada: mogućnosti revitalizacije i obnove starog Ivanića, pp. 1-11. Zagreb, Hrvatska sekcija ECOVAST-a. 